\title{
Performance of Silver Leaf Fern Pteris Ensiformis 'Victoriae' and Spider Plant Chlorophytum Comosum 'Vittatum' in Various Growing Media'
}

\author{
Saulo J. Rodriguez and Carlos Rivera-López ${ }^{2}$
}

\begin{abstract}
The silver leaf fern Pteris ensiformis 'Victoriae' was planted in different growing mixtures under artificial shade. The peatmoss in the University of California and Cornell Peat-Lite mixtures was substituted by dry coffee leaves, sugarcane bagasse, spent ground coffee, Caño Tiburones muck or wood shavings. Neither the University of California sand-peatmoss mixture nor substitutions of peatmoss were suitable for growing in hanging baskets. The Cornell Peat-Lite mixtures A and B were adequate for proper growth of silver leaf fern in hanging baskets. Dry coffee leaves, sugarcane bagasse, spent ground coffee and Caño Tiburones muck were adequate substitutes for peatmoss in the Cornell mixtures. Vermiculite, perlite, or Styrofoam did not improve growth over peatmoss alone. The potting qualities of fresh spent ground coffee were improved by the addition of calcined clay, perlite or Cialitos clay (an Oxisol) as shown by the growth of the spider plant, Chlorophytum comosum 'Vittatum'.
\end{abstract}

\section{INTRODUCTION}

Growing ornamental plants for local consumption and export has developed into a 4 million dollars agribusiness in Puerto Rico. The authors reported recently on various trials to obtain a suitable local substitute for peatmoss in growing media $(2,3)$. They reported on two potting media for Asparagus sprengeri and Pelargonium under greenhouse conditions. They found several local materials, dry coffee leaves and muck soil, suitable substitutes for peatmoss in potting mixtures.

This paper presents results obtained in Puerto Rico with potting materials in hanging basket trials.

\section{MATERIALS AND METHODS}

Eighty green plastic hanging baskets, $8^{\prime \prime}$ in diameter, were filled with different growing mixtures. Although the mixtures were based on University of California and Cornell Peat-Lite mixtures (1), the various treatments consisted of substituting peatmoss in those mixtures with materials found

${ }^{1}$ Submitted to the Editorial Board July 29, 1974.

2 Horticulturist and Agronomist, Plant Breeding Department, Agricultural Experiment Station, Mayagüez Campus, University of Puerto Rico, Río Pierras, P.R. 
locally such as dry coffee leaves, muck soil, sugarcane bagasse, and wood shavings. Two treatments were included additionally: pure peatmoss and peatmoss-Styrofoam.

Uniform silver leaf fern, Pleris ensiformis 'Victoriae' plants were obtained from a local nursery. They were bought in a styrofoam-peatmoss mixture in four-inch plastic pots and transplanted to hanging baskets by removing most of the previous mixture without materially damaging the root system.

The plants were placed under a 76 percent polypropylene shade cover. They were distributed in a 20 -treatment, $4 \times 5$ partially balanced rectangular lattice design with four replicates. Irrigation was applied when needed through flexible capillary tubes with lead "drop in" weights. A cup of a 30-10-10 soluble fertilizer mixture at the rate of one tablespoon per gallon was applied biweekly to each plant.

The plants were evaluated visually after 3 months by a twelve-person panel on a 1 to 5 point rating on general appearance. A 5 point rating was given to a plant with the best appearance, a 1 point value to the poorest growing plant. The panel had experience in evaluating ornamental plants. Mean values of the twelve evaluations were used in the statistical analysis.

Plantlets of spider plant Chlorophytum comosum 'Vittatum' were placed in 6-inch white plastic pots. The bulbils were uniform in size and source. The plastic pots contained a 1:1 combination of spent fresh ground coffee with each one of the following materials: wood shavings, Cialitos clay, coffee parchment, Cataño sand, calcined clay or perlite.

The plants were placed in a Latin square design on a greenhouse work bench. Temperature and light were partially controlled. They were irrigated daily through a capillary tube system. A 30-10-10 water soluble fertilizer solution was applied weekly.

All plants were harvested at the same time when the first bulbil appeared in any plant. The plants were separated into top and root growth. The material was weighed both fresh and air-dried.

All data were analyzed through variance, and the means were compared in a multiple range test at the 5 percent level of significance.

\section{RESULTS AND DISCUSSION}

Silver leaf fern results are presented in table 1. None of the plants differed statistically among themselves when the variable filling materials were mixed separately with sand. However, they were inferior to the other standard mixture materials, wood shavings excepted. Plants growing in the wood shavings-vermiculite treatment were statistically inferior to those growing in peatmoss or Caño Tiburones muck mixed with vermiculite. The other materials mixed with vermiculite produced plants as good as those on peatmoss. In the perlite treatments, when mixed with wood shavings, the treat- 
ment again gave the poorest plants of the group and the plants were inferior statistically to those with peatmoss or sugarcane bagasse in the mixture.

Many nurserymen in Puerto Rico are using peatmoss with Styrofoam. The results, as shown in table 1, show definitely that the addition of Styrofoam to peatmoss does not improve plant quality. After three weeks under

TABLE 1.-Effect of different mixing materials on the visual appearance of silver leaf fern Pteris ensiformis 'Victoriae' grown in hanging baskets

\begin{tabular}{|c|c|c|c|c|c|}
\hline \multirow{2}{*}{$\begin{array}{l}\text { Variable filling } \\
\text { materials }\end{array}$} & \multicolumn{5}{|c|}{ Standard Mixture Materials } \\
\hline & Sand ${ }^{2}$ & Vermiculite $^{2}$ & Perlite & Peatmoss & Styrofoam \\
\hline Peatmoss & 2.88 def $^{4}$ & $4.71 \mathrm{a}$ & $4.50 \mathrm{ab}$ & $4.48 \mathrm{ab}$ & $4.15 \mathrm{abcd}$ \\
\hline Coffee dry leaves & $2.15 \mathrm{f}$ & 3.90 abcde & 3.43 abcdef & & \\
\hline Sugarcane bagasse & $2.65 \mathrm{ef}$ & 3.49 abcde & 3.64 abcde & & \\
\hline Spent ground coffee & 3.18 bcdef & $4.13 \mathrm{abcd}$ & $4.35 \mathrm{ab}$ & & \\
\hline Caño Tiburones muck & $2.84 \mathrm{def}$ & $4.21 \mathrm{abc}$ & 3.55 abcde & & \\
\hline Wood shavings & $2.82 \mathrm{def}$ & 2.84 def & 2.94 cdef & & \\
\hline
\end{tabular}

1 The standard University of California mixture is a $1: 1$ combination by volume of sand and peatmoss.

2 The Cornell Peat-Lite Mixture A consists of vermiculite and peatmoss in equal volumes to which a given quantity of limestone, fertilizer and superphosphate is added.

${ }^{3}$ In Cornell Peat-Lite Mixture B; vermiculite substituted by perlite.

1 All adjusted values are means of four replications. A 5-point rating was given to plants with excellent appearance, and a 1-point value to plants with poorest appearance. Means with the same letter or set of letters do not differ significantly at the 5-percent level.

TABLE 2.-Effect of different substances on the improvement of the potting quality of spent fresh ground coffee as reflected on the growth of the spider plant,

Chlorophytum comosum 'Vittatum' under greenhouse conditions

\begin{tabular}{l|r|r|r|r}
\hline \multicolumn{1}{c|}{ Treatment' } & \multicolumn{2}{|c|}{ Fresh weight in } & \multicolumn{2}{|c|}{ Air-dry weight in g } \\
\cline { 2 - 5 } & Aerial & Roots & Aerial & Roots \\
\hline Spent fresh ground coffee + wood shavings & $4.67 \mathrm{c}^{2}$ & $6.09 \mathrm{~b}$ & $\mathbf{0 . 4 0 \mathrm { c }}$ & $\mathbf{0 . 4 3 \mathrm { b }}$ \\
Spent fresh ground coffee + Cialitos clay & $15.93 \mathrm{a}$ & $7.76 \mathrm{~b}$ & $1.31 \mathrm{a}$ & $.88 \mathrm{ab}$ \\
Spent fresh ground coffee + coffee parchment & $8.17 \mathrm{bc}$ & $11.06 \mathrm{~b}$ & $.73 \mathrm{bc}$ & $.77 \mathrm{ab}$ \\
Spent fresh ground coffee + Cataño sand & $13.88 \mathrm{ab}$ & $9.79 \mathrm{~b}$ & $1.10 \mathrm{ab}$ & $.47 \mathrm{~b}$ \\
Spent fresh ground coffee + calcined clay & $18.84 \mathrm{a}$ & $21.88 \mathrm{a}$ & $1.16 \mathrm{ab}$ & $1.23 \mathrm{a}$ \\
Spent fresh ground coffee + perlite & $13.32 \mathrm{ab}$ & $18.82 \mathrm{a}$ & $1.58 \mathrm{a}$ & $1.15 \mathrm{a}$ \\
\hline
\end{tabular}

1 The treatments were mixed in a 1:1 proportion by volume.

2 Treatments with same letter or set of letters do not differ significantly at 5-percent level. 
cover some plants also showed definite deleterious effects of the wind due to their succulency. Plants in perlite mixtures were less affected apparently by wind. This aspect requires further investigation.

The results obtained with the spider plant are presented in table 2. Calcined clay or perlite are suitable for mixing with spent ground coffee to improve potting quality. Previous results showed a tendency for the mixture to separate from the pot walls and to form a surface crust (3).

\section{RESUMEN}

Se sembró el helecho Pteris ensiformis 'Victoriae' en canastas plásticas colgantes que contenian mezclas de varios ingredientes. Los resultados reflejaron que la mezcla de California a base de arena y musgo turboso no era apropiada para el crecimiento. Los mismo ocurrió con las substituciones del musgo de pantano por materias locales. Las mezclas livianas de Cornell basadas en vermiculita y perlita fueron adecuadas para el crecimiento del helecho en canastas. Lo mismo se puede decir de la substitución del musgo turboso por hojarasca de café, bagazo de caña de azúcar, borra de café o suelo orǵ́nico del Caño Tiburones. Las mezclas que contenían musgo puro o musgo con partículas de "Styrofoam" fueron tan buenas como las que contenian vermiculita o perlita. En adición, se encontró que la borra de café puede mejorarse como material para las mezclas con la adición de arcilla calcinada o perlita según se reflejó por el crecimiento de la planta araña Chlorophytum comosum 'Vittatum'.

\section{LITERATURE CITED}

1. Hartman, H. T. and Kester, Dale E., Plant Progagating Principles and Practices, Chap. 1, pp. 33-6, 2nd ed, Prentice-Hall, Inc., Englewood Cliffi, N. J., 1968.

2. Rodriguez, Saulo J., and Rivera-López, Carlos, The Performance of Pelargonium Stockplants in Different Potting Mixtures. (Submitted for publication.)

3. - - - and Santiago, Alejandro, Performance of Asparagus sprengeri and Dracaena sanderiana in Different Potting and Rooting Media, J. Agr. Univ. P.R. $57(4)$ : 314-9, 1973. 